serious scientific study of the possibilities of low temperature gas-storage of fresh fruit and vegetables, and its success has already led to the erection of several commercial gas-stores for apples. Problems connected with the corrosion of cans by fruit juices and syrups have been surveyed; the transport and storage of bacon and pork as well as freezing and storage of meat and eggs are all receiving attention, while it has also been found that temperatures below $0^{\circ} \mathrm{F}$. are required for the storage of brine-frozen haddock. Other investigations at the Torrey Research Station are concerned with the design of plant for the extraction of liver oil on steamtrawlers at sea and for the smoke-curing of fish, and it is not too much to claim that the national im. portance of the food investigations of the Department alone justify a large proportion of the whole expenditure on scientific and industrial research. Certain it is that few fractions of the national income are more wisely administered or expended with more profit both to society and to industry than the comparatively small sums which are entrusted by Parliament to the Department of Scientific and Industrial Research.

\title{
Obituary
}

\section{Prof. R. Stenhouse Williams}

$\mathrm{P}$ ROF. R. STENHOUSE WILLIAMS, first director of the National Institute for Research in Dairying, who died on Feb. 2 at the age of sixty years, went to Reading in 1912 equipped for the study of the dairying industry with a thorough knowledge of bacteriology, a science for which he had the greatest reverence and the status of which he jealously guarded. His profession as a physician and his academic career assisted him in the broad outlook which he brought to bear on the industry of his adoption. As a medical man he realised the importance of the nation's milk supply ; as a bacteriologist he was scandalised by the conditions which were associated with milk production, and as a teacher he deplored the apathy and ignorance which tolerated such conditions.

With a characteristic thoroughness, Prof. Stenhouse Williams set himself to study the position, and brought his science and personal observation to bear on every stage in the passage of milk from the cow to the consumer. He did not content himself merely with working out scientific technique for the production of a clean and safe milk supply; he also realised the difficulties of the practical side and the necessity of keeping down the cost of production. It was here that his special gift of inspiring efficient social service came into full play. He became the friend of the farmer and of the milk distributor, inspiring in all with whom he came in contact the right mentality for their especial duties. Every grave error in the handling of milk he treated as a mistake which could be overcome by care and co-operation, and no hour of the day was too early or too late for him to give help and advice in cow byre or distributing centre.

Prof. Stenhouse Williams realised the necessity for technical education in all branches of the milk industry, and was active in the organisation of lectures, classes, and competitions with the view of increasing both the knowledge and efficiency of the workers. He was a man of very clear vision. $\mathrm{He}$ saw the foundations on which the unique nutritional value of milk is established in the order of Nature, and demonstrated on a large and convincing scale that pure and safe milk could be produced as a practical proposition. He emphasised that the work of the research institute for which he was responsible should rest on the firm foundations of fundamental science, and he stressed the necessity for a very thorough further study of the nutritional value of milk, including all possible effects produced by heat treatment. In his fight to maintain an open door for raw milk, many have crossed swords with him who could not have realised the soundness of his contention that the present necessity of harnessing the milk supply of our large towns to any processing machine is an expedient which must not exclude the recognition of a possible clean and natural milk supply under better conditions of social service.

Great and lasting as is his achievement in this work, it was the character and personality of Stenhouse Williams himself which endeared him to those who knew him well. To others, who differed from him, he presented an uncompromising front, for he was by nature a fighter.

\section{Prof. W. H. Watkinson}

WE regret to reeord the death, on Feb. 14, of William Henry Watkinson, emeritus professor of engineering and director of the Walker and Harrison Hughes Engineering Laboratories of the University of Liverpool.

Prof. Watkinson, who was in his serenty-second year, was born at Keighley. His early training in the University of Glasgow brought him under the direction of Lord Kelvin, and, under the latter and Prof. Fleeming Jenkin, he aided in the manufacture, testing, and laying of trans-Atlantic cables. For a time he held a scholarship under Kelvin, and in 1888 was put in charge of the Engineering Department of the Central Science School, Sheffield. In 1893 he was appointed to the chair of engineering in the Glasgow and West of Scotland Technical College.

In 1905, Watkinson was appointed to the chair of engineering in Liverpool, and was largely responsible for the growth of that school. His efforts for engineering resulted in the building and equipment, in 1912, of the beautiful laboratories which he later directed. He was also instrumental in the foundation of the chairs of naval architecture and thermodynamics in Liverpool.

Watkinson's personal investigations related in particular to pioneer work on gas engines and air

$$
\text { No. 3252, VoL. 129] }
$$

